\title{
The effect of using balanced scorecard (BSC) on reducing production costs in the Jordanian industrial companies
}

\author{
Ashraf Bataineh \\ Ziyad AL- Shwiyat \\ Ashraf Alrjoub
}

Department of Financial and Administrative Sciences

AL-Balqa Applied University/ Irbid University College, Jordan.

\section{Keywords}

Balanced Scorecard (BSC), reducing production costs, financial perspective, customers' perspective, internal processes perspective, and learning and growth perspective.

\begin{abstract}
The study aims to measure the effect of using balanced scorecard (BSC); with its different perspectives on reducing production costs in the Jordanian industrial companies. The study depends on the questionnaire which was addressed to the financial managers, accounting department heads, managerial and costs accountants. The study sample contained (171) employees working in the Jordanian industrial companies. It used the descriptive, analytical, and also the regression analysis methods. The study results showed a significant effect of using the following BSC perspectives (financial perspective, customers' perspective, internal processes perspective, and learning and growth perspective) on reducing production costs in the Jordanian industrial companies. The study recommended that industrial companies should keep paces with the rapid changes taking place in the manufacturing environment, and continuously encourage those companies to innovate their employees.
\end{abstract}

Corresponding author: Ashraf Bataineh

Email addresses for the corresponding author: bataineh_ashraf@bau.edu.jo

First submission received: $6^{\text {th }}$ April 2018

Revised submission received: $2^{\text {nd }}$ July 2018

Accepted: $20^{\text {th }}$ July 2018

\section{Introduction}

The organizations today aim to increase their earnings or at least sustains it by reducing production costs and controlling it, and most of these organizations adopt costs reduction as a factor of business strategy by relying more on the strategic management accounting techniques to arrive to wastefree processes, achieve costs and expenditures saving, and other tangible business advantages. The BSC method, which was developed by Norton, and Kaplan considers a useful strategical technique for costs management through improving customer's services, reducing their costs, and assessing the successes of organization's strategies, and have been implemented by the organizations which are growing rapidly, as a mechanism to help them manage their performances and strategies effectively. The BSC welcomed at most of the current and significant developments in the field of managerial or costs accounting, which combines the traditional performance measurements with the leading indicators of future financial performance in a framework that connect the organizational strategies and the operational measurements together. Despite the privilege that BSC has been awarded as a system or technique to evaluate performance, it didn't transform into a major tool to develop and evaluate the strategies, considering that main performance measurements can be divided into four main categories, which are: financial, customer, internal business processes, and learning and growth (Upton,2012).

The BSC introduces information about the executive managers from four different aspects, adopting several managerial mechanisms, and in the same time reducing information density by combining the used procedures. Former managerial experience with the BSC recognized essential 
components for reducing costs by improving processes. BSC was widely implemented at the logistic and manufacturing firms (Kim \& Cavusgil \&Calantone, 2006).

BSC looks at organizational performance as integration between the financial measures and other major performance indicators, such as customers, internal business processes, and learning and growth, which enable the organizations to follow their operational and financial results; on a short period and the growth level in the long run (Ghosh \& Mukherjee, 2006). BSC not only assist organizations to measure their performance, but also to figure out the necessary strategies to achieve the long-term goals (Tseng, 2010). Therefore, this research determines the effect of BSC perspectives on reducing production costs in the Jordanian industrial companies.

\section{Study problem}

The industrial sector in Jordan, today falls under tremendous developments and economical changes in the information and production technology, that made the industrial companies in this sector vulnerable to local and global severe competition and pressures, which drive those companies to use one of the strategic management accounting methods represented in the BSC, which works through its integrated perspectives, in order to reduce production costs in those companies and help them to survive and persist (Rababah \& Bataineh, 2016).

Therefore, problem of the study can be represented in the following question:

"Is there an effect for using BSC perspectives (financial, customers, internal processes and learning and growth) on reducing production costs in the Jordanian industrial companies?"

\section{Study objectives}

The study aims to reach the following objectives:

- Identify the effect of using BSC perspectives (financial, customers, internal processes, and learning and growth perspective) on reducing costs in the Jordanian industrial companies.

- Identify the most important obstacles and difficulties that may prevent the use of BSC perspectives in the Jordanian industrial companies.

- Make recommendations that serve the Jordanian industrial companies in using BSC perspectives for reducing production costs, therefore enhancing the competitive advantage.

\section{Study importance}

The significance of this hypothetical research comes from its topic, "The effect of using the BSC perspectives on reducing production costs in the Jordanian industrial companies"; and this may be correct in view of the technological developments and advancements on the national and international level, which led to raise the competition level in several sectors, such as industrial sector as one of the fundamental aspects of economic growth due to its effect on society. It was essential to look into the prospective of BSC; in this sector since it contains the required information that may assist industrial companies in making the decision related to production and reducing production cost, which help those companies compete in the marketplace.

\section{Conceptual framework}

\subsection{Balanced Scorecard}

BSC, which has attracted nowadays much attention, is not only a comprehensive and integrated measurement tool for performance, but also a management system with a new approach of strategic cost management and was developed by Norton and Kaplan in the 1990s to measurements of financial and nonfinancial performance (Bazrkar \& Iranzadeh, 2017). BSC method measures company performance in four main business perspectives, financial, customers, internal processes, and learning and growth (Kaplan \& Norton, 1992).

\subsubsection{Financial perspective}

Financial perspective considers the most significant perspective of all, particularly in relation to the major strategy execution and evaluation of organizations' performances. It put emphasis on the 
company long-term objectives, in term of returns increase and productivity enhancement (Carmona \& Iyer \& Reckers, 2011). Normally, it occupies the highest section of BSC, and achieved through the requirements of organisations' mission and vision statements, and the conversion of financial concerns into maintainable objectives and minimum costs (Niven, 2011).

\subsubsection{Customer perspective}

This perspective concentrates on customers long lasting relationships and services, which measure the level of organizations commitment to attract, maintain, and meet the needs of customers (Seyed \& Taleghani \& Bakhsha \& Partovi, 2011), and depending on (Kaplan and Norton, 1992), there are two criteria used for measurement, the first one is "centralized measurement group" which includes maintaining customers, market shares, customers satisfaction, achievements, and customers profitability, while the second one is "next performance driver" which leads the organization to the place of customer value, and include leading times, quality, product and quality characteristics, image, and relationship.

\subsubsection{Internal process perspective}

This perspective concentrates on information collected about customer needs to be used for selling new products and services and divides the normal value chain activities in the organization into four process levels, which are: innovation, customers relationship management, operational processes, and regulations and environment. The maintenance process influences the production cost effectiveness, in relation to its effect on the several consumed resources in company's operations, as an example, work forces assigned to production line, may be idle during shut down, overtime hours may be necessary to cover some of the production waste (Alsyouf, 2006).

\subsubsection{Learning and growth perspective}

This perspective connects with employee capabilities, and business processes, in order to manage the companies and adapt to its changing environment (Huang \& Lai \& Lin, 2011).Learning and growth considers two primary features that organizations, in general have to integrates it into their strategies, and there are different types of primary pointers and intangible assets, where it's possible to implement it to show and explain these features, which includes (Chuang, 2007): human being, information, organization capital, alignment, and teamwork. Therefore, companies should implement the measurement methods it need, instead of the one that it capable of doing, and this prospective will be measure through the organizational capabilities related to the capital, employees, and knowledge systems on the one hand, and significance of establishing organizational communication value on the other hand, knowing that, intellectual capital efforts will focus on investment in the staffs responsible for critical internal processes, to achieve the superior level (Kaplan \& Norton, 2004).

\subsection{Reducing production costs}

According to the association for low costs operations, the definition of costs is the expense resource for achieving the added value of processes and results, and in order to reach the target goals, the expected costs and expenses must be met, which can be calculated and measured by the currency (American Accounting Association, 2008). BSC took a main role during the previous few years, by assisting companies to deal with the multiple requirements and needs, such as reduce costs, increase product assortments, improve product quality, and dependable delivery date through proficient and efficient coordination between the production and distribution activities (Czuchry, 2009).

Reducing costs is important, it shows as a major goal in the industrial companies for the sake of gaining profits, and capitalizing on those profits, where companies won't be able to stay in business without collecting rational profit ratios (Carenys \& Sales, 2008). These companies are able to achieve this goal, by controlling their activities, by providing the finest products at the lowest prices, or reducing the product costs in order to compete in the market with other companies. The preparation and utilization of cost lists help to determine the defined product costs, and it will show after investigating costs collected from the different departments in the company, if the costs are acceptable or not, and see how far we can reduce and control costs by analyzing the size of the economy. 
Nevertheless, the manufacturing costs take an important role, because it affects costs and mainly there is a need to reduce it, and there are many ways and methods to help reduce production costs (Rababah \& Bataineh, 2016), and this research will focus on reducing costs in the industrial companies, through operational performance, storage optimization, and the use of raw materials. The results probably represent direct effect through the production process and waste reduction, by operating the inventory level approach. Shortly, this direct effect may be represented or introduced small quantity purchases, which leads to less storage requirements, and lower operational and fixed costs.

\section{Literature reviews}

This study establishes an analytical model to review BSC perspectives, and criteria measures. In addition, this study proposes reducing production costs by using BSC:

\section{6-1 Balanced Scorecard (BSC)}

The study of (Darvish \& Mohammadi \& Afsharpour, 2012) illustrated the effect of knowledge management measurement figures on the advancement of four BSC perspectives, and showed a positive important relationship between the knowledge management model and the four perspectives of BSC, while (Al Sawalqa \& Holloway \& Alam, 2011) in his study implemented an economic perspective BSC at the Jordanian industrial companies, and found companies that adopted BSC employed different perspectives in their BSC, with large concentration on the original four perspectives proposed by Kaplan and Norton. The paper done by (Davis \& Albright, 2004) recommended that BSC is a widespread and detailed performance assessment tool for the effective planning and controlling of the organization, in order to achieve the desired goals.

However (Jassbi \& Mohamadnejad \& Nasrollahzadeh, 2011), in a latest study moved toward BSC by using the mapping strategy, which is the process of visually creating cause and effect relationships between all feasible strategic purposes, and could be observed as a united general assembly that meets together to make decisions related to the cause and effect relationships inside a structural modelling framework by adopting the downgrade technique as an approach that focus on the problem. (Kaplan \& Norton, 2006) added that customer perspective considers a significant component of company's reengineering process, while (Sandberg, 2001) insisted that reducing costs and improving quality should be part of the processor- engineering process. Re-engineering stands for re-modelling business processes, in order to improve the existing performance, which can be accomplished by reducing costs, improving quality, and satisfying customer needs, and (Horngreen \& Datar \& Foster , 2006) proposed that in order to reengineer the system effectively, it would be crucial to engage all company's operations, such as reengineering product quality by reducing deficiency levels and increasing product values, and the reengineering process by reducing delivery time of products or services, but (Czuchry \& Mahmoud \& Damir,2009) declared that innovation, learning and growth, customer's satisfaction are crucial for the company's strategic success, and its future, therefore adopting BSC will support the manufacturers to implement criteria, such as reducing defects and production costs, and increasing productivity.

\section{6-2 Reducing production costs}

Costs is a kind of disbursement or payment that companies pay out for the production and manufacturing process, and according to (Webner, 1911) production costs per unit is the costs associated with production, divided by the number of units produced, and reducing these costs as (Carroll, 1953) mentioned may assist companies to maintain a competitive edge. Cost categories, as said by (Jinkens \& Yallapragada, 2010), are the numerous types of expenses that companies should keep in mind, when producing products or providing services, and it's possible to divide these categories into fixed and variable costs or management and financial costs, and in general cost structure contains the following types: labor, material, R\&D, and transportation costs. The study of (Compton \& Brinker, 2005) stated there are different type of costs, and only few of those may be used to assist the decision-making process, where researchers are splited up on the type of these costs, for example (Compton \& Brinker, 2005) divided it into minor and ruined costs, while (Martin, 1992) split it into direct, distributable, third-party, associated, and indirect costs, but (Webner, 1911) considered three essential elements of production costs which are 
represented in labors, materials, and general expenses, and (Watts, 1902) supposed that production costs includes manufacturing supplies, special cost items, materials, labors, and general expense.

Reducing cost is a dynamic and continuous process that includes cost examination, analysis, and challenges which represented in the standard, where (Mersereau \& Nijander \& Townsend, 1994) expressed that reducing costs can be found everywhere in the company, such as productions, manufacturing, methods, organization, processes, and also staffs. Furthermore, (Murphy \& Schramm \& Doherty \& Reichley \& Gajic \& Afessa \& Kollef, 2009) stated that reducing costs is significantly inspected and evaluated, in order to improve efficiency and effectiveness while (Bruce, 1992) identified that reducing cost is applying procedures to check the spending and performance, in light of the projected growth, comparing the manufacturing operations with the predictable finishing point to measure discrepancy from the approved budgets, and allowing decision makers to take an effective procedures and steps to reach the lowest cost possible, and depending on what (Carroll, 1953) said, it's crucial that companies adopt the reducing costs strategy every time it goes through rough time or looks for future growth.

\section{Methodology}

\section{7-1 Sample characteristics and data collection}

The study used the survey method and the descriptive and verify for data type. The study population consists of (54) industrial companies listed in the Amman Stock Exchange (www.ASE, 2017), (Bataineh \& Rababah, 2016) and data were made up of primary and secondary data. Primary data were obtained directly from the respondents through questionnaire. The questionnaire was designed and sent to companies in the study sample to be filled by four categories: financial managers, heads of accounting departments, administrative accountants, and costs accountants (4 questionnaires for each company). Questionnaire distributed to (171) members of the workers in the Jordanian industrial companies that are related to measuring the study variables. Secondary data were obtained through a literature review and via the internet. Data were processed and analyzed using the linear regression, as part of the computerized statistical program for social science (SPSS).

\section{7-2 Research hypotheses}

The following hypotheses have been tested in this study:

Main hypothesis $\mathrm{H}_{01}$ : There is no statistically significant effect for using balanced scorecard perspectives (financial, customers, internal processes, and learning and growth) on reducing production costs in the Jordanian industrial companies.

Sub-hypothesis $\mathrm{H}_{01-1}$ : There is no statistically significant effect for using financial perspective on reducing production costs in the Jordanian industrial companies.

Sub-hypothesis $\mathrm{H}_{01-2}$ : There is no statistically significant effect for using customers' perspective on reducing production costs in the Jordanian industrial companies.

Sub-hypothesis $\mathrm{H}_{01-3}$ : There is no statistically significant effect for using internal processes perspective on reducing production costs in the Jordanian industrial companies.

Sub-hypothesis $\mathrm{H}_{01-4}$ : There is no statistically significant effect for using learning and growth perspective on reducing production costs in the Jordanian industrial companies.

\section{Study Analysis}

\section{8-1 Tests related to study instrument}

First: validity of the tool: This process aims to check whether the tools used in this study actually measure the construct it was developed to measure (Sekaran \& Bougie, 2014). Validity tests employed in this study included:

\section{Face validity}

This test aims to ensure that the paragraphs which contain in the study tool can lead to collecting data accurately, and to achieve this goal the questionnaire was introduce to number of specialists, from the 
faculty members of several Jordanian universities, in order to identify the clarity and easiness level of paragraphs used in the study tool.

\section{Content validity}

This sincerity and validity mean to make sure that every field or dimension of the study are represented accurately by a set of paragraphs that related to the field, and that paragraphs in fact measure this field (Sekaran \& Bougie, 2014), where the validity of the questionnaire contents measure the relationship between the items or paragraphs and the dimensions it represent, by using Pearson correlation coefficient. The confidents higher than $(30 \%)$ were employed at the significance level of $(0.05 \geq a)$ (AL-Shwiyat, 2013). Table (1) shows the existence of statistically significant relationship at level $(0.05 \geq a)$ among the items of the variable, which indicate the construct validity of the items:

Table (1): Pearson correlation coefficients of the variables

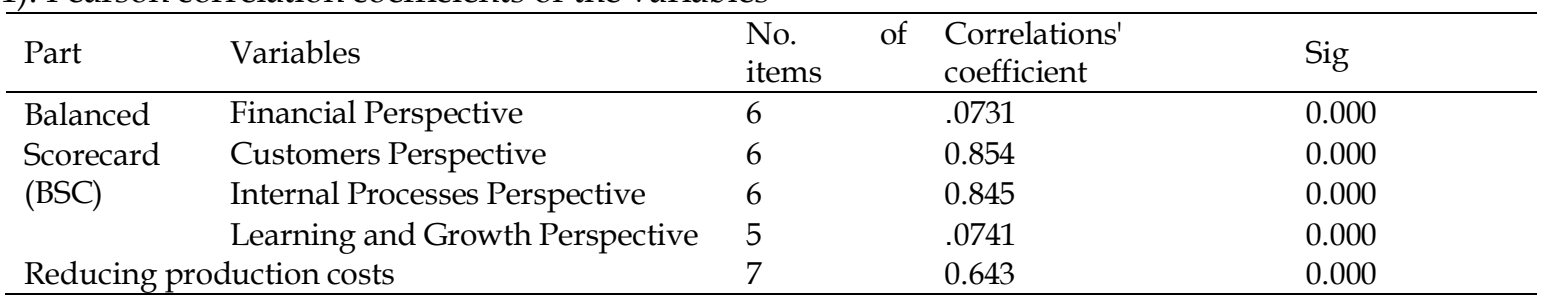

Factor analysis: The factor analysis was applied with the principal comment on the responses of the study sample on the items, the loading and communalities values of each factor was calculated for each variable. Table (2) revealed that all loadings and communalities for all factors were high and pointed out that most of statistical resources accepted these results in case they were higher than (0.35) (Sekaran\& Bougie, 2014).

Table (2) the value of loadings and communalities

\begin{tabular}{|c|c|c|c|c|c|c|c|c|}
\hline \multicolumn{6}{|c|}{ Balanced Scorecard (BSC) \%of Variance: (27.882\%) } & \multicolumn{3}{|c|}{$\begin{array}{l}\text { Reducing Production Costs } \\
\% \text { of Variance: }(24.813 \%)\end{array}$} \\
\hline No. & Loadings & Communalities & No. & Loadings & Communalities & No. & Loadings & Communalities \\
\hline 1 & 0.524 & 0.475 & 13 & 0.622 & 0.487 & 24 & 0.586 & 0.558 \\
\hline 2 & 0.452 & 0.421 & 14 & 0.643 & 0.522 & 25 & 0.512 & 0.442 \\
\hline 3 & 0.471 & 0.477 & 15 & 0.653 & 0.614 & 26 & 0.461 & 0.416 \\
\hline 4 & 0.661 & 0.425 & 16 & 0.571 & 0.527 & 27 & 0.818 & 0.677 \\
\hline 5 & 0.657 & 0.455 & 17 & 0.668 & 0.454 & 28 & 0.887 & 0.786 \\
\hline 6 & 0.604 & 0.526 & 18 & 0.591 & 0.554 & 29 & 0.870 & 0.756 \\
\hline 7 & 0.692 & 0.475 & 19 & 0.680 & 0.471 & 30 & 0.807 & 0.652 \\
\hline 8 & 0.548 & 0.518 & 20 & 0.691 & 0.488 & & & \\
\hline 9 & 0.465 & 0.417 & 21 & 0.558 & 0.428 & & & \\
\hline 10 & 0.649 & 0.422 & 22 & 0.498 & 0.444 & & & \\
\hline 11 & 0.592 & 0.453 & 23 & 0.568 & 0.554 & & & \\
\hline 12 & 0.580 & 0.385 & & & & & & \\
\hline \multicolumn{5}{|c|}{ Kaiser-Meyer-Olkin Measure of Sampling Adequacy. } & 0.845 & Sig. & & 0.000 \\
\hline
\end{tabular}

\section{Second: Reliability test:}

Tool constancy and stability means the possibility of accessing and getting the same data when repeating the study, using the same study tool on the same study sample members; individuals themselves and in similar circumstances, and to measure the reliability of each variable separately, and for the tool as a whole, the internal consistency measure (Cronbach's Coefficient Alpha), where the acceptable value is (70\%) and more (Sekaran \& Bougie, 2014). Table (3) revealed that correlation values were high 
and ranged from (0.743) to (0.871) with an average of (0.905), which is above (0.70). This leads to accept the reliability of the study instrument.

Table (3): Cronbach's Coefficient Alpha

\begin{tabular}{llll}
\hline Part & Variable & No. of items & Cronbach's Coefficient Alpha \\
\hline & Financial Perspective & 6 & 0.812 \\
Balanced & Customers Perspective & 6 & 0.763 \\
$\begin{array}{l}\text { Scorecard } \\
\text { (BSC) }\end{array}$ & Internal Processes Perspective & 6 & 0.743 \\
& Learning and Growth Perspective & 5 & 0.828 \\
Reducing production costs & 7 & 0.871 \\
Total average & 30 & 0.905 \\
\hline
\end{tabular}

\section{Third: Normal distribution}

(One-Sample Kolmogorov - Smirnov Test) was performed to see if data follow a normal distribution or not, which is a necessary test in case of hypotheses testing; because most parametric tests require normal data distribution, and table (4) shows that all values of statistical significance for the (OneSample Kolmogorov-Smirnov Test) for the independent variables and the dependent variable weren't statistically significance at the significance level $(a \leq 0.05)$, which indicate that independent variables and the dependent variable follow the normal distribution.

Table (4): One-Sample Kolmogorov - Smirnov Test

\begin{tabular}{|c|c|c|c|c|}
\hline Part & Variable & No. of Items & K-S Z & Sig. \\
\hline \multirow{4}{*}{$\begin{array}{l}\text { Balanced } \\
\text { Scorecard } \\
\text { (BSC) }\end{array}$} & Financial Perspective & 6 & 0.876 & 0.452 \\
\hline & Customers Perspective & 6 & 0.716 & 0.452 \\
\hline & Internal Processes Perspective & 6 & 0.982 & 0.231 \\
\hline & Learning and Growth Perspective & 5 & 0.669 & 0.468 \\
\hline \multicolumn{2}{|c|}{ Reducing production costs } & 7 & 0.891 & 0.184 \\
\hline \multicolumn{2}{|c|}{ Total average } & 30 & 0.754 & 0.361 \\
\hline
\end{tabular}

\section{8-2 Characteristics of the study sample}

Table (5) revealed that the highest percentage sample of $(36.3 \%)$ was for the age group (From $35<$ 44 years), and the second ranked in the age group was (From $25<34$ years) with $(28.7 \%)$, while the highest percentage sample of $(37.4 \%)$ was to the experience group (From $11<15$ years), and the second ranked in the experience group (More than 15 years) with (28.1\%). In regard to the qualification group, the highest percentage of the sample was (62\%) in favor of Bachelor's degree holders, and the second ranked to postgraduate and diploma degree holders with (19.3\%) and (18.7\%) orderly, and in relation to the job description category, the highest percentage sample of $(40.4 \%)$ was to the group cost accountant, and second ranked in the group was management accountant, with (39.2\%), but as far as the specialization category, the results indicate the highest percentage of (76.6\%) was for the sample accounting specialization, followed by financial specialization with only $(15.8 \%)$. The results indicate that most participants are mature enough to limit the effect for using BSC perspectives (financial, customers, internal processes, and learning and growth perspective) on production costs reduction in the Jordanian industrial companies.

Table (5) demographical characteristics of the respondents

\begin{tabular}{lll}
\hline Categories & Frequency & Percentage \\
\hline Age & 12 & 7.0 \\
Less than 25 years & 49 & 28.7
\end{tabular}

www.jbrmr.com A Journal of the Academy of Business and Retail Management (ABRM) 


$\begin{array}{lll}\text { From } 35<44 \text { years } & 62 & 36.3 \\ \text { 45 years and more } & 48 & 28.1 \\ \text { Experience } & & \\ >5 \text { years } & 7 & 4.1 \\ \text { From } 5<10 \text { years } & 48 & 28.1 \\ \text { From 11<15 years } & 64 & 37.4 \\ \text { More than 15 years } & 52 & 30.4 \\ \text { Qualification } & & \\ \text { Diploma } & 32 & 18.7 \\ \text { Bachelor } & 106 & 62.0 \\ \text { Postgraduate } & 33 & 19.3 \\ \text { Job description } & & \\ \text { Financial manager } & 10 & 5.8 \\ \text { Head of department } & 25 & 14.6 \\ \text { Management accountant } & 67 & 39.2 \\ \text { Cost accountant } & 69 & 40.4 \\ \text { Specialization } & & \\ \text { Accounting } & 131 & 76.6 \\ \text { Financial } & 27 & 15.8 \\ \text { Business administration } & 9 & 5.3 \\ \text { Economic } & 4 & 2.3 \\ \text { Total } & 171 & 100.0\end{array}$

\section{8-3 Hypotheses Test}

Before testing the hypotheses, the suitability of the data must be tested for the linear regression analysis between two or more variables, and the parametric tests, therefore regression model were examined to verify the absence of a high reciprocal links between the independent variables, where (Barrow, 1988 ), (Anderson \& Sweeney \& Williams, 1993),(bataineh, 2018) pointed that the existence of correlation over $(70 \%)$ between two or more independent variables, considered a high correlation that could result in distortion of the relationship between one of the variables and the dependent variable, and therefore it will be difficult to explain and interpret the relationship between them, and to check for the non-existence of this problem at the regression models used in this study, the reciprocal correlations matrix has been prepared between the independent study variables. Table (6) shows that correlation coefficient between each pair of the independent variables isn't high, suggesting that the results of the regression model aren't affected by the multi-co linearity.

Table (6): Correlation analysis for independent variables

\begin{tabular}{lllll}
\hline Variable & Financial & Customers & Internal Processes & $\begin{array}{l}\text { Learning and } \\
\text { Growth }\end{array}$ \\
\hline Financial Perspective & 1.000 & & & \\
$\quad$ Customers Perspective & $0.588^{* *}$ & 1.000 & & \\
I Internal Processes Perspective & $0.474^{* *}$ & $0.419^{* *}$ & 1.000 & 1.000 \\
LLearning \& Growth Perspective & $0.338^{* *}$ & $0.502^{* *}$ & $0.572^{* *}$ & \\
\hline
\end{tabular}

**Correlation is significant at the 0.01 level (2-tailed).

Autocorrelation Tests were conducted to verify that data are free of any autocorrelation problem in the regression model, which weakens the model ability to make prediction, and (Durbin Watson Test) was used to verify this problem, where this test consider the most widely used, and (Bashir, 2003) showed the ideal result for this test to be between (1.5-2.5), which refer to the non-existence of autocorrelation between the variables. The analysis results showed that the value of calculated (D-W) amounted to (1.693), and according to the basic rule, this value fall within the appropriate range, indicating that data are free of any autocorrelation problem, and therefore valid for use in the regression model.

\section{8-4 testing the hypothesis}

To investigate the hypothesis, which state: "There is no statistically significant effect for using the BSC perspectives (financial, customers, internal processes, and learning and growth) on reducing 
production costs in the Jordanian industrial companies", the multiple linear regression and stepwise multiple regression were implemented to find out the effect of using BSC on reducing production costs. Table (6) indicate the existence of statistically significant effect at level $(\alpha \geq 0.05)$ for the use of BSC on reducing production costs, where the value of the correlation coefficient amounted to $(\mathrm{R}=0.719)$, which is statistically significance value, and indicate a strong positive correlation between using the BSC and reducing production costs, and also the value of the adjusted R-Square reached (0.511), which shows the combined independent variables to be capable of interpreting (51.1\%) from variation in the dependent variable (reducing production costs). The table also shows that T-test (F-statistic) value at (74.654) with a statistical significance (0.000), which is statistically significance at level $(\alpha \geq 0.05)$ and indicate the existence of statistically significance relationship between the independent variables combined and the dependent variable.

Table (7): Multiple Linear Regression for the effect of BSC on Reducing Production Costs

\begin{tabular}{|c|c|c|c|c|c|c|}
\hline Variables & $\begin{array}{l}\text { Expected } \\
\text { sign }\end{array}$ & Coefficient & T-Statistic & Prob & Tolerance & $\mathrm{VIF}^{*}$ \\
\hline (Constant) & & 1.906 & 6.620 & 0.004 & & \\
\hline Financial Perspective & +1 & 0.185 & 4.051 & 0.000 & 0.526 & 1.902 \\
\hline Customers Perspective & +1 & 0.297 & 4.972 & 0.000 & 0.327 & 2.564 \\
\hline Internal Processes Perspective & $+/-$ & 0.198 & 3.671 & 0.000 & 0.353 & 2.833 \\
\hline $\begin{array}{l}\text { Learning and Growth } \\
\text { Perspective }\end{array}$ & $+/-$ & 0.159 & 3.421 & 0.002 & 0.548 & 1.825 \\
\hline $\mathrm{R}$ & 0.719 & & atistic & & 74.642 & \\
\hline R-squared & 0.582 & & (F-statistic) & & 0.000 & \\
\hline Adjusted R Square & 0.511 & & bin-Watson & tistic & 1.693 & \\
\hline
\end{tabular}

* All VIF values less than (10), and refer to the non-existence of any autocorrelation problem

According to the results of table (7), there is a positive statistical significant effect at level $(\alpha \geq 0.05)$ of Financial Perspective on Reducing Production Costs, (at Coefficient $=0.185, p>0.000$ ), this indicates that the increase of one degree in Financial Perspective leads to Reducing Production Costs by (18.5\%), and this also ensures that T-Statistic Value of (4.051) was a positive value, and statistically significant at level $(\alpha \geq 0.05)$, there is a positive statistical significant effect at level $(\alpha \geq 0.05)$ of Customers Perspective on Reducing Production Costs, (at Coefficient $=0.297, p>0.000$ ), which indicates that the increase of one degree in Customers Perspective leads to Reducing Production Costs by $(29.7 \%)$, and also ensures that TStatistic Value of (4.972) was a positive value, and statistically significant at level ( $\alpha \geq 0.05)$, and the results also revealed a positive statistical significant effect at level $(\alpha \geq 0.05)$ of Internal Processes Perspective on Reducing Production Costs, (at Coefficient $=0.198, p>0.000$ ), which indicates that the increase of one degree in Internal Processes Perspective leads to Reducing Production Costs by (19.8\%), and also ensures the T-Statistic Value of (3.671) was positive value, and statistically significant at level ( $\alpha \geq 0.05)$, and finally, there was a positive value, and statistically significant at level $(\alpha \geq 0.05)$ of Learning and Growth Perspective on Reducing Production Costs, (at Coefficient $=0.159, \mathrm{p}>0.000$ ), which indicates that increase of one degree in Learning and Growth Perspective leads to Reducing Production Costs by (15.9\%), and also ensures the T-Statistic Value of (3.421) was positive value, and statistically significant at level ( $\alpha \geq$ 0.05). Therefore, we reject the null hypothesis and accept the alternative hypothesis which stated: "There is statistically significant effect for using balanced scorecard perspectives (financial, customers, internal processes, and learning and growth) on reducing production costs in the Jordanian industrial companies".

To determine which balanced scorecard used variable, had the most impact on reducing production costs in the Jordanian industrial companies listed at Amman financial market, the (Stepwise Multiple Regression) analysis has been implemented, and the following table shows the results of this test: 
Table (8) stepwise multiple regression) BSC on Reducing Production Costs)

\begin{tabular}{|c|c|c|c|c|c|c|c|c|}
\hline BSC & B & $\begin{array}{l}\text { Std. } \\
\text { Error }\end{array}$ & $\mathrm{T}$ & Sig. & $\mathrm{R}$ & $\begin{array}{l}\text { Adjusted } \\
\text { R Square }\end{array}$ & $\mathrm{F}$ & Sig. \\
\hline (Constant) & 1.270 & 0.194 & 6.492 & 0.000 & \multirow{2}{*}{0.603} & \multirow{2}{*}{0.362} & \multirow{2}{*}{161.26} & \multirow{2}{*}{0.000} \\
\hline Customers Perspective & 0.649 & 0.049 & 12.698 & 0.000 & & & & \\
\hline (Constant) & 0.911 & 0.185 & 4.887 & 0.000 & \multirow{3}{*}{0.681} & \multirow{3}{*}{0.461} & \multirow{3}{*}{121.61} & \multirow{3}{*}{0.000} \\
\hline Customers Perspective & 0.471 & 0.051 & 8.890 & 0.000 & & & & \\
\hline Financial Perspective & 0.301 & 0.039 & 7.231 & 0.000 & & & & \\
\hline (Constant) & 0.629 & 0.191 & 3.265 & 0.004 & \multirow{4}{*}{0.705} & \multirow{4}{*}{0.492} & \multirow{4}{*}{92.05} & \multirow{4}{*}{0.000} \\
\hline Customers Perspective & 0.345 & 0.057 & 5.834 & 0.000 & & & & \\
\hline Financial Perspective & 0.256 & 0.040 & 6.136 & 0.000 & & & & \\
\hline Internal Processes Perspective & 0.230 & 0.053 & 4.246 & 0.000 & & & & \\
\hline (Constant) & 1.906 & 0.188 & 6.620 & 0.004 & \multirow{5}{*}{0.719} & \multirow{5}{*}{0.511} & \multirow{5}{*}{74.64} & \multirow{5}{*}{0.000} \\
\hline Customers Perspective & 0.297 & 0.058 & 4.972 & 0.000 & & & & \\
\hline Financial Perspective & 0.185 & 0.044 & 4.051 & 0.000 & & & & \\
\hline Internal Processes Perspective & 0.198 & 0.052 & 3.671 & 0.000 & & & & \\
\hline $\begin{array}{l}\text { Learning and Growth } \\
\text { Perspective }\end{array}$ & 0.159 & 0.045 & 3.421 & 0.002 & & & & \\
\hline
\end{tabular}

Table (8) shows that (Customers Perspective) explain the amount of (36.2\%) from the variation in reducing production costs, and that (Customers Perspective, Financial Perspective) explain the amount of (46.1\%) from the variation in reducing production costs, and the percentage for explaing the overall variation in (reducing production costs) increased to (49.2\%), after adding the variable (Internal Processes Perspective) to the (Customers Perspective, Financial Perspective), and finally the overall variation explanation ratio in the (reducing production costs) increased to (51.1\%), by adding the variable (Learning and Growth Perspective) to the previous variables. This shows the importance of these variables effect on reducing production costs at the industrial companies listed in Amman financial market, and also the different $(F)$ levels in all models were within the significant level (Sig. 0.000), which ensure a significant regression.

By reviewing the regression coefficients results, we find that $(\beta)$ values in all models, at different levels of (T), are located at the significant level (Sig. 0.000), and for all the variables within the Stepwise Multiple Regression models, and all of it came less than $(0.05 \%)$, which confirm the significant of the regression coefficients, and indicates that the effect of variables are statistically significant. According to that it's possible to create the Stepwise Multiple Regression formula for the variables, as follows:

$Y=\beta_{0}+\beta_{1} X 1+\beta 2 X 2+\beta 3 X 3+\beta 4 X 4+E_{i t}$

$Y=0.198$ (Financial Perspective) +0.185 (Customers Perspective) $+0.1 .906+0.297+$ (Internal Processes Perspective) +0.159 (Learning and Growth Perspective) +0.188

\section{Discussions}

The result of this study confirms the effect of Using BSC on Reducing Production Costs in the Jordanian Industrial Companies. The findings of this study focused on the previous studies, which acknowledged the effect of using BSC perspectives (financial perspective, customers' perspective, internal processes perspective, and learning and growth perspective) in the industrial companiess to developing competitive business environment (Al Sawalqa et.al, 2011; Kaplan \& Norton, 2006; Czuchry et.al,2009). The present study found that $71.9 \%$ of Jordanian industrial companies recognized the importance of Using BSC perspectives to Reduce Production Costs in this companies.

Hypotheses; $\mathrm{H}_{01-1}$ : indicates that financial perspective has a significant effect on Reducing Production Costs. The result shows that financial perspective was able to explain $18.5 \%$ of Reducing Production Costs in the Jordanian Industrial Companies. The result of this study is consistent with the previous studies such as (Davis \& Albright, 2004; Al Sawalqa et.al, 2011). $\mathrm{H}_{01-2}$ : point out that 29.7\% of Customers Perspective has more significant effect on Reducing Production Costs in the Jordanian Industrial Companies. This result is reliable with the earlier studies (Kaplan \& Norton, 2006; Czuchry et.al,2009). $\mathrm{H}_{01-3}$ : as expected the result confirmed that Internal Processes Perspective has a significant 
effect on on Reducing Production Costs. The result shows that perspective was able to explain 19.8\% of Reducing Production Costs in the Jordanian Industrial Companies. $\mathrm{H}_{01-4}$ : indicates that learning and growth perspective has a significant effect on Reducing Production Costs. The result shows that learning and growth perspective was able to explain 15.9\% of Reducing Production Costs in the Jordanian Industrial Companies. The result of this study is consistent with the previous studies such as (Czuchry et.al,2009). Based on the above, we stress on rejecting the null hypothesis and accepting the alternative hypothesis.

\section{Conclusions}

Through the analysis, test, and discussion of the study hypotheses, the study arrived to the following most important conclusions:

Jordanian industrial companies use the BSC at high degree to provide information for the different functional units, and arrive to a variety of decisions and solutions, which serve the workflow, and that (Learning and Growth Perspective) considers the most BSC methods used, while the (Financial Perspective) considers the least used.

There is a positive effect for using the BSC, with its perspectives on reducing production costs in the Jordanian industrial companies, where the customers perspective considered the most influential on reducing production costs with $(29.7 \%)$, then the internal processes with $(19.8 \%)$, followed by the financial perspective of the BSC with (18.5\%), and lastly came the learning and growth with the least effect of $(15.9 \%)$. In addition, using the BSC, can explain (51.1\%) of the changes that happened on reducing production costs in the Jordanian industrial companies.

Jordanian industrial companies work to reduce production costs, through developing the existing cost systems in the company to improve the accuracy of calculating production costs, by using many mathematical, statistical, and accounting tools, which consider one of the successful controlling methods on the production costs.

\section{Recommendations}

The researcher made the following recommendations:

Companies should examine other factors that have effect on reducing production costs, through studying the factors related to management internal control systems and internal control systems, and their level of impact on reducing production cost.

Increase the interest of companies to the theories, methods, and procedures of change and development in the performance and productivity, and avoid and stay away from the unplanned strategies, to improve production in the environment that characterized by the speed of change and complexity.

Companies need to conduct periodic meetings between management and employees, that aim to identify the importance of using perspectives of BSC, and its role in raising the efficiency of reducing production costs.

The need to care about information systems, considering its analytical systems that offer extensive possibilities, for prediction, analysis, planning, along with providing renewable databases that support decision making.

\section{Limitation and scope of the study}

The study is limited to the industrial companies listed in the Amman Stock Exchange. Also, this study examined only four of BSC perspectives to reduce production costs. With regards to the source of data, the present study used the questionnaire to measure the study variables. However, the present study suggested that future studies should consider the limitations as mentioned above, to provide a more comprehensive result and validate the current findings.

This study will assist future research to examine the effects of using all BSC perspectives on reducing the products costs for the stages of value chain in retail sectors. It will also bring attention of the policy makers and practitioners to use BSC perspectives in the retail sectors in particular. 


\section{References}

AL-Shwiyat, Ziyad Mustafa (2013), The impact of Social Responsibility on the Financial Performance for Jordanian Companies, European Journal of Business and Management, Vol.5, No.30, pp 123- 132.

Alsyouf, I. (2006). Measuring maintenance performance using a balanced scorecard approach. Journal of Quality in Maintenance Engineering, 12(2), 133-149.

Al-Sawalqa. F; Holloway, D; \& Alam, M, (2011). Balanced Scorecard Implementation in Jordan: An Initial Analysis.; International Journal of Electronic Business Management, 9(3), pp. 196-210.

American Accounting Association (2008). http://aaahq.org/

Anderson, D.R., Sweeney, D.R. and Williams, T.A. (1993), Statistics for Business and Economics, Fifth Edition, West Publishing Company, St. Paul, MN.

Barrow, M. (1988) Statistics for Economics, Accounting and Business Studies, Longman Group UK Limited, UK.

Bashir, S. Z. (2003), the statistical program, SPSS, Central Bureau of Statistics, Department of Statistics, Baghdad, Iraq.

Bataineh, A. (2018). Applicability of activity-based costing in the Jordanian hospitality industry. International Journal of Economics and Business Research, 15(4), 475-489.

Bataineh, A., \& Rababah, A. (2016). Comprehensive Income and Net Income, which is more powerful in predicting Future Performance. International Journal of Academic Research in Accounting, Finance and Management Sciences, 6(2), pp 114-120.

Bazrkar, A., \& Iranzadeh, S. (2017). Choosing a strategic process in order to apply in Lean Six Sigma methodology for improving its performance using integrative approaches of BSC and DEA. Journal of Business and Retail Management Research, 11(4), pp 114-123.

Bruce A, M, (1992), Aspects of Cost Control, Cost Engineering, 34(6), pp 19-23.

Carenys, J., \& Sales, X. (2008). Costing the banking services: a management accounting approach. Journal of money, investment and banking, 6(1), pp 8-9.

Carmona, S., Iyer, G., \& Reckers, P. (2011). The impact of strategy communications, incentives and national culture on balanced scorecard implementation. Advances in Accounting, p. 1-13. doi: 10.1016/j. adiac. 2011. 01. 004.

Carroll, P, 1953, How to Control Production Costs, New York, McGraw-Hill, USA.

Chuang, M. (2007). The Balanced Scorecard: Creating a management system for private technical universities in Taiwan. (3243815 Ed.D.), Spalding University, Kentucky, United States. Retrieved from https://vpn.utm.my/docview/ 304741860? Accounted=41678 ProQuest Dissertations \& Theses Full Text.

Compton, J \& Brinker, M, Jr, (2005), How do we Define "Cost", Journal of Financial Service Professional, 59(5), pp 1617.

Czuchry, A., Mahmoud, Y., \& Damir K. L. (2009). Enhancing organizational effectiveness through the implementation of supplier parks: The case of the automotive industry. Journal of International Business Research 8(1) pp45-61.

Darvish, H., Mohammadi, M., \& Afsharpour, P. (2012). Studying the Knowledge Management-Effect of Promoting the Four Balanced Scorecard Perspectives: A Case Study at SAIPA Automobile Manufacturing. Economic InsightsTrends \& Challenges, 64(1), pp 9-23.

Davis, S., \& Albright, T. (2004). An investigation of the effect of balanced scorecard implementation on financial performance. Management accounting research 15(2), pp 135-153.

Jassbi, J., Mohamadnejad, F., \& Nasrollahzadeh, H. (2011). A Fuzzy DEMATEL framework for modeling cause and effect relationships of strategy map. Expert systems with Applications, 38(5), pp 5967-5973.

Jinkens, R., \& Yallapragada, R. R. (2010). Cost Accounting in Auto Manufacturing Companies in Germany and the United States. The International Business \& Economics Research Journal, 9(3), pp 121-126.

Horngren, C. T., \& Datar, S. M. Foster G, (2006), Cost Ac-counting: A Managerial Emphasis.

Huang, H, Lai, M, \& Lin, L. (2011), Developing strategic development and improvement for the biopharmaceutical firm: Using the BSC hierarchy. Expert Systems with Applications 38, (2011). 4875-4881. Retrieved from Academic One File via Gale.

Ghosh, S., \& Mukherjee, S. (2006). Measurement of corporate performance through Balanced Scorecard: an overview. Journal of Commerce 11(6), pp 60-68.

Kaplan, R., Norton, D. (2004). Strategy Maps: Converting Intangible Assets into Tangible Outcomes (Boston, MA: Harvard Business School Press).

Kaplan, R. and Norton p. (1992). The balanced scorecard: Measures that Drive performance, Harvard Business Review, USA, 70(1), 71-79.

Murphy, C. V., Schramm, G. E., Doherty, J. A., Reichley, R. M., Gajic, O., Afessa, B., ... \& Kollef, M. H. (2009). The importance of fluid management in acute lung injury secondary to septic shock. Chest, 136(1), pp 102-109.

Niven, P. R. (2011). Balanced scorecard: Step-by-step for government and nonprofit agencies. John Wiley \& Sons. Second Edition.

www.jbrmr.com A Journal of the Academy of Business and Retail Management (ABRM) 
Mersereau, K.O., Nijander, C.R. and Townsend, W.P., AT\&T Corp, 1994. Method for making microstructures. U.S. Patent 5,370,768

Martin, B, A (1992) "Aspects of Cost Control", Cost Engineering; 34, 6, pp19-23

Rababah A, Bataineh A. (2016) Factors influencing balanced scorecard implementation. Research Journal of Finance

23. and Accounting; 7(2): pp 204-212.

Kim, D., Cavusgil, S. T., \& Calantone, R. J. (2006). Information system innovations and supply chain management: channel relationships and firm performance. Journal of the Academy of Marketing Science, 34(1), pp $40-54$

Sandberg, K. D. (2001). Reengineering Tries a Comeback - This Time for Growth, Not Just Cost Savings. Harvard Management Update, 6(11), pp 3-6.

Seyed hosseini, S. M., Taleghani, A. E., Bakhsha, A., \& Partovi, S. (2011). Extracting leanness criteria by employing the concept of Balanced Scorecard. Expert Systems with Applications, 38(8), pp10454-10461.

Tseng, M. (2010). Implementation and performance evaluation using the fuzzy network balanced scorecard. Computers \& Education, 55(1), pp188-201.

Upton, D; (2012). Experimental Balanced Scorecard Research: Implications for Practitioners. Management Accounting Quarterly.13 (4) pp 25-31.

Watts, C (1902), the cost of production, Muskegon, The Shaw-Wallker company.

Webner, F E, (1911), Factory Costs, New York, The Ronald press company, USA.

www.ASE.com.jo/ (ASE) Amman Stock Exchange 2017. 